\title{
Association between Hepatitis B Virus and Celiac Disease Patients in Khartoum State, Sudan
}

Shiraz Gamal ${ }^{1 *}$, Khalid Enan², Mohammed Hussien², Mustafa El-tigani' ${ }^{1}$ and Isam Elkhidir ${ }^{3}$

${ }^{1}$ Department of Microbiology, Faculty of Medical Laboratory Sciences, Al Neelain University, Khartoum, Sudan ${ }^{2}$ Central Laboratory, Ministry of Science and Technology Khartoum, Sudan

${ }^{3}$ Department of Microbiology and Parasitology, Faculty of Medicine, University of Khartoum, Khartoum, Sudan

\begin{abstract}
Background: It has been hypothesized that non-intestinal inflammatory diseases such as hepatitis B virus (HBV) and hepatitis C virus (HCV) may trigger immunological gluten intolerance in susceptible people. This hypothesis suggests a possible epidemiological link between these two diseases.

Method: ELISA third generation for Hepatitis B surface antigen (HBsAg) was used in 131 blood samples of patients with seropositive and seronegative for celiac disease (CD). Positive and negatives ELISA samples were confirmed using PCR for detection of HBV DNA. Data on various variables were collected from patients CD using a structured questionnaire after taking informed consent.

Results: The prevalence of HBs Ag detected in seropositive celiac disease was $9.9 \%$ by serology (ELISA) and $8.5 \%$ using PCR PCR detected two samples out of $64(3.1 \%)$ as positive for HBV DNA which were negative by HBs Ag ELISA which indicated occult HBV infection. No statistical significant was difference $(P>0.05)$ among subjects when distribution of HBV was studied on the basis of age and gender.

Conclusions: The results herein reported that there was an association between HBV and CD in the Khartoum State, Sudan as evident from the significantly higher prevalence of HBV infection in CD patients compared to CD seronegative patients included in the current study.
\end{abstract}

Keywords: Hepatitis B Virus (HBV); Celiac Disease (CD); Khartoum State; Sudan

\section{Introduction}

Celiac disease $(\mathrm{CD})$ is an autoimmune disorder of the small intestine that affects in genetically predisposed subjects of all age groups (from middle infancy onward CD is due to a reaction to gliadin, a prolamin (gluten protein), and similar proteins found in other crops Vis barley and rye [1]. CD symptoms include chronic diarrhea, fatigue, weight loss, weakness and classic steatorrhea. Abdominal pain, nausea and vomiting are uncommon. Most symptoms are related to malabsorption (extensive lesion in the proximal duodenum to the distal ileum produces resulting in severe malabsorption), pedal edema, protein malabsorption, easy bruising and vitamin $\mathrm{K}$ deficiency due to malabsorption.

Diagnoses in asymptomatic CD patients are based on persons as a result of increased screening; [2]. Serological tests are the first-line for investigations that could establish a diagnosis of CD Anti-gliadin IgG and IgA antibodies, Tissue transglutaminase (tTG), response to diet endoscopy scalloping of folds and "cracked-mud" appearance of mucosa. Further investigations may be performed to associate complications, such as iron, folic acid and $\mathrm{B}_{12}$ deficiency, hypocalcaemia and thyroid_function tests [3].

The association between $\mathrm{CD}$ and several liver disorders has long been documented. About $40 \%$ of adult CD patients have been reported to have a mild to moderate hyper transaminasemia (up to five times the upper normal limit) at the time of diagnosis of $C D[4,5]$. An increased prevalence of autoimmune hepatitis among CD patients has been reported [6,7]. The recent publication by Leonardi and La Rosa (2010) has established the prevalence of CD in patients with chronic HBV [8].

It had been hypothesized that chronic HBV could trigger immunological gluten intolerance in susceptible individuals [9]. This hypothesis, however, has not yet been supported by sufficient scientific evidence and data.
The objective of this study was to elucidate the possible association between HBV infection and celiac patients in Khartoum State, Sudan.

\section{Materials and Methods}

\section{Data collection}

Ethical approval from the Federal Ministry of Health and informed consent regarding data were obtained for collection and examination of blood samples. The collected data included, gender, age and clinical symptoms including abdominal distension, anaemia, diarrhea and growth retardation. The obtained data were analyzed using statistical package (SPSS) version 9.

\section{Inclusion criteria and sample collection}

A total of 131 blood samples (71 CD seropositive, $60 \mathrm{CD}$ seronegative) were collected from hospitals in Khartoum State (Khartoum teaching Hospital, Omdurman teaching Hospital, Bashaier teaching Hospital and Gaffer Ibn Auf Children Hospital). Five ml of blood were collected from positive and negative $\mathrm{CD}$ in plain vacotainer from the cubital vein, centrifuged at $4000 \mathrm{rpm}$ for 5 minutes to separate the serum. The separated serum was stored at $-20^{\circ} \mathrm{C}$ until use.

*Corresponding author: Shiraz Gamal, Department of Microbiology, Faculty of Medical Laboratory Sciences, Al Neelain University, Khartoum, Sudan, Tel: +249912170926; E-mail: shiry.start44@gmail.com

Received February 24, 2013; Accepted March 27, 2013; Published March 31, 2013

Citation: Gamal S, Enan K, Hussien M, El-tigani M, Elkhidir I (2013) Association between Hepatitis B Virus and Celiac Disease Patients in Khartoum State, Sudan. Clin Microbial 2: 107. doi:10.4172/2327-5073.1000107

Copyright: ( 2013 Gamal S, et al. This is an open-access article distributed under the terms of the Creative Commons Attribution License, which permits unrestricted use, distribution, and reproduction in any medium, provided the original author and source are credited. 


\section{Serology}

\section{ELISA technique}

Commercial Sandwich ELISA Kits for detection of hepatitis B virus antigen (HBsAg) were purchased from WKEA, NEW YORK, USA. In brief, Polystyrene micro-titer strip wells have been coated with monoclonal anti-HBs (antibody to HBsAg), which constitutes the solid-phase antibody. Each serum sample was incubated in the well; if HBsAg is present in the sample, it binds to the solid-phase antibody. Subsequently, guinea-pig anti-HBs, which has been labeled with the enzyme horseradish peroxides (HRP), was added. In a positive reaction this labeled antibody became bound to any solid-phase antibody HBsAg complex previously formed. Incubation with enzyme substrate produced a blue colour in the well, which turned yellow when the reaction was stopped with sulphuric acid. If the sample contained no HBsAg, the labeled antibody cannot be bound specifically and only a low background colour developed. Results were read at $450 \mathrm{~nm}$ according to the manufacturer's instruction. The Cut-off value was estimated by calculating the mean absorbance value for three negative controls $\left({ }^{*} \mathrm{NC} \times 2.1\right)$.

\section{DNA extraction}

DNA was extracted from $200 \mu \mathrm{L}$ of serum as described by LIN and FLOROS. A total of $250 \mathrm{~mL}$ of serum was treated with proteinase $\mathrm{K}$ and $5 \%$ SDS (Sigma Aldrich, Saint-Quentin Fallavier, France) at $65^{\circ} \mathrm{C}$ for $1 \mathrm{~h}$. This solution was then heated at $95^{\circ} \mathrm{C}$ for $10 \mathrm{~min}$ to inactivate the proteinase $\mathrm{K}$. The lysate was then extracted by phenol and precipitated by ethanol. After a centrifugation at $16000 \mathrm{~g}, 4^{\circ} \mathrm{C}$ for $15 \mathrm{~min}$, the DNA pellet was dissolved in $25 \mathrm{ul}$ of Tris-HCL $10 \mathrm{mM} \mathrm{pH} 8.5$.

\section{Polymerase chain reaction (PCR)}

PCR for HBV were performed using primer pairs HBV-F 5 TCGGAAATACACCTCCTTTCCATGG-3HBV-R 5 GCCTCAAGGTCGGTCGTTGACA-3 PCR master mix for one reaction was prepared as follows: $2.5 \mu \mathrm{l} 10 \mathrm{X}$ buffer , $0.75 \mu \mathrm{l} \mathrm{MgSO} 4,0.5 \mu \mathrm{l}$ dNTPs , $2 \mu \mathrm{l}$ each primers, $0.25 \mu \mathrm{l}$ Taq polymerase, $14 \mu \mathrm{l}$ molecular grade water and $5 \mu \mathrm{l}$ genomic DNA. The final volume was $25 \mu \mathrm{l}$ for a single reaction. The reaction was performed in an automated PCR (Biorad, USA) for 35 cycles. Each cycle consisted of $5 \mathrm{~min}$ at $94^{\circ} \mathrm{C}, 95^{\circ} \mathrm{C}$ for 30 seconds, $62^{\circ} \mathrm{C}$ and $72^{\circ} \mathrm{C}$ for $1.30 \mathrm{~min}$ followed by a final step at $72^{\circ} \mathrm{C}$ for $5 \mathrm{~min}$.

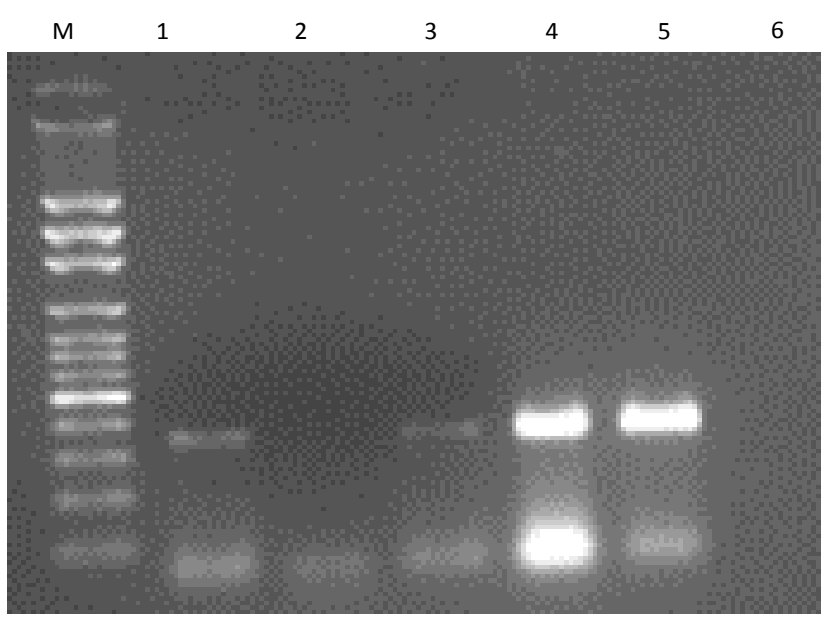

Figure 1: HBV PCR results ( $350 \mathrm{bp}$ ) on $1.5 \%$ agarose gel. Lanes $1-4$ show PCR results in four patients; Lane 6 shows negative, Lane 5: Positive control, M: 100 bp DNA size marker.

\begin{tabular}{|c|c|c|c|c|}
\hline Technique & PCR + & PCR - & Total & Concordance (\%) \\
\hline ELISA + & 4 & 3 & 7 & \multirow{2}{*}{$93 \%$} \\
\cline { 1 - 4 } ELISA - & 2 & 62 & 64 & \\
\hline Total & 6 & 65 & 71 & \\
\hline
\end{tabular}

Table 1: Cross-tabulation between PCR and ELISA results for the detection of $\mathrm{HBsAg}$ in seropositive celiac disease patients in Khartoum State, Sudan.

The amplified PCR products were electrophoresed on $2 \%$ agrose gel and visualized with UV light after staining with ethidium bromide.

\section{Result}

HBsAg was detected in 7 out of 71 (9.9\%) seropositive celiac disease patients by ELISA and 6 out of $71(8.5 \%)$ were positive for HBV DNA by PCR (Figure1). None of the 60 seronegative celiac disease patients were positive for HBV infection by ELISA and PCR. The mean age of seropositive cases was $8.4 \%$ year (with an average range of 1 to 31 year), $70 \%$ of them were male and $30 \%$ females. There was no significant difference $(\mathrm{P}>0.05)$ in seroprevalence among age, patients based on gender.

\section{Comparison of ELISA and PCR results}

The cross-tabulation between PCR and ELISA is shown in (Table 1). A total of 71 samples that were tested using the two techniques were used to compare the results between the ELISA and PCR. Of these, 6 samples were positive by PCR, 4 were positive by both ELISA and PCR, 3 were positive by ELISA only and 62 were negative by both methods. All PCR negatives samples were found also negative by ELISA except for 3 samples, which were negative by PCR. This revealed an overall agreement of $93 \%$ (66/71) between the two tests.

\section{Discussion}

It has been hypothesized that non-intestinal inflammatory diseases may trigger immunologic gluten intolerance in susceptible subjects $[10,11]$. HBV were thought to be suitable candidates. However, this assumption is still debatable. Meagre data on the relationship between $\mathrm{HBV}$ and $\mathrm{CD}$ is available literature, although one third of the world's population has been infected with HBV [12]. It has been reported that the response to $\mathrm{HBV}$ vaccination in $\mathrm{CD}$ individuals was lower than in the general population $[13,14]$. Consequently, it is also possible that HBV like HCV may trigger immunological gluten intolerance in genetically susceptible people and that chronic HBV represent a higher percentage of CD patients.

The present study was focused on association between seropositive celiac disease and chronic hepatitis B infection in Khartoum State, Sudan. The prevalence of HBsAg detected in seropositive celiac disease was $9.9 \%$ by serology (ELISA) and $8.5 \%$ using PCR. Bardella et al. [4] reported a study in which the prevalence of HBsAg in celiac disease patients was $2.5 \%$, twice the rate reported in general population of Northern Italy, confirming a hypothetic link between celiac disease and HBV infection.

The prevalence of celiac auto antibodies in chronic hepatitis $B$ patients was 9.1\% (8/88). Leonardi and Rosa [8] conducted a serological testing for celiac disease antibodies in chronic hepatitis B subjects but a linkage between hepatitis B infection and serologically-defined celiac disease could not be established. This may be attributed to the limited sample size of their hepatitis B cohort screened for celiac disease antibodies.

Possible activation of celiac disease due to the treatment of hepatitis infection is another controversial point. There have been some reports 
Citation: Gamal S, Enan K, Hussien M, El-tigani M, Elkhidir I (2013) Association between Hepatitis B Virus and Celiac Disease Patients in Khartoum State, Sudan. Clin Microbial 2: 107. doi:10.4172/2327-5073.1000107

Page 3 of 3

indicating that autoimmune disorders such as celiac disease can develop during treatment with interferon $\alpha$ (IFN- $\alpha$ ) for viral hepatitis. Celiac disease activation during IFN- $\alpha$ or IFN- $\alpha$ plus ribavirin therapy has been observed in HCV-positive patients, confirming that IFN- $\alpha$ therapy could trigger celiac disease in susceptible subjects during treatment.

In the results, all PCR negative samples were found also negative for HBsAg except for three samples, which were negative by PCR and positive by ELISA. This may due to low viral load so PCR could not able to detect HBV DNA.

In this study, PCR detected two samples as positive for HBV DNA which was negative by HBsAg ELISA. This result indicates the presence of occult hepatitis B virus (HBV) infection (OBI) in which sensitive HBV DNA amplification assay is the gold standard assay for detection though, the absence of HBs Ag.

To the best of our knowledge, this is the first record showing an association between celiac disease and HBV infection in Sudan. Further studies might also need to directly examine intestinal biopsies, not only for histological evidence of celiac disease, but for evidence of prior viral "foot prints".

The high prevalence of anti-HBV antibodies herein reported may be related to the autoimmune environment that had triggered an abnormal response to gliadin. Similarly, hepatitis B and hepatitis C, which may have amino acid sequences homologous to the toxic epitopes in gliadin, could trigger immunological gluten intolerance in susceptible subject [15].

Analysis of $H B V$ seropositivity rates with respect to gender revealed that males were $70(53.4 \%)$ and females were 61 (46.6\%). This in agreement with Leonardi and La Rosa [8], in fact, a typical population manifesting $\mathrm{CD}$ is mostly comprised of young adults, with twice as many women as men.

Moreover, prevalence as much as $1 \%$ of the general population [16], and it is possible that the association available literature is the result of incidental findings in a population most studied for the underlying disease. Therefore, scale, not only in Khartoum State, but at the country level should be conduct to investigate the prevalence of CD in individuals HBV and HCV. Such a study should also include an analysis of the HLA genotype, which seems to may have played a major rule in such and association.

\section{Acknowledgement}

This study was supported by Department of Microbiology, Faculty of Medical Laboratory Sciences, Al-Neelain University, Khartoum, Sudan. We acknowledge Khartoum State hospitals (Khartoum teaching Hospital, Omdurman teaching Hospital, Bashier teaching Hospital and Gaffer Ibn Auf Children Hospital), for technical help.

\section{References}

1. Di Sabatino A, Corazza GR (2009) Coeliac disease. Lancet 373: 1480-1493.

2. van Heel DA, West J (2006) Recent advances in coeliac disease. Gut 55: 1037 1046.

3. Presutti RJ, Cangemi JR, Cassidy HD, Hill DA (2007) Celiac disease. Am Fam Physician 76: 1795-1802.

4. Bardella MT, Fraquelli M, Quatrini M, Molteni N, Bianchi P, et al. (1995) Prevalence of hypertransaminasemia in adult celiac patients and effect of gluten-free diet. Hepatology 22: 833-836.

5. Volta U, De Franceschi L, Lari F, Molinaro N, Zoli M, et al. (1998) Coeliac disease hidden by cryptogenic hypertransaminasaemia. Lancet 352: 26-29.

6. Volta $U$ (2009) Pathogenesis and clinical significance of liver injury in celiac disease. Clin Rev Allergy Immunol 36: 62-70.

7. Volta U, Rodrigo L, Granito A, Petrolini N, Muratori P, et al. (2002) Celiac disease in autoimmune cholestatic liver disorders. Am J Gastroenterol 97: 2609-2613.

8. Leonardi S, La Rosa M (2010) Are hepatitis B virus and celiac disease linked? Hepat Mon 10: 173-175.

9. Rubio-Tapia A, Murray JA (2007) The liver in celiac disease. Hepatology 46: 1650-1658.

10. Fine KD, Ogunji F, Saloum Y, Beharry S, Crippin J, et al. (2001) Celiac sprue: another autoimmune syndrome associated with hepatitis C. Am J Gastroenterol 96: $138-145$

11. Bardella MT, Fraquelli M, Quatrini M, Molteni N, Bianchi P, et al. (1995) Prevalence of hypertransaminasemia in adult celiac patients and effect of gluten-free diet. Hepatology 22: 833-836.

12. WHO Publication (2010) Hepatitis B vaccines: WHO position paper-recommendations. Vaccine 28: 589-590.

13. Ahishali E, Boztas G, Akyuz F, Ibrisim D, Poturoglu S, et al. (2008) Response to hepatitis $B$ vaccination in patients with celiac disease. Dig Dis Sci 53: 2156-2159.

14. Park SD, Markowitz J, Pettei M, Weinstein T, Sison CP, et al. (2007) Failure to respond to hepatitis B vaccine in children with celiac disease. J Pediatr Gastroenterol Nutr 44: 431-435.

15. Fine KD, Ogunji F, Saloum Y, Beharry S, Crippin J, et al. (2001) Celiac sprue: another autoimmune syndrome associated with hepatitis C. Am J Gastroentero 96: 138-145.

16. Rubio-Tapia, A. Murray, J.A Gluten-sensitive Enteropathy. In: Metcalfe, D.D. Sampson, H.A.; Simon, R.A. (2003) editors. Food allergy: adverse reactions to food and food additives: Wiley-Blackwell; p. 245-57. 